\title{
Создание и концептуальные основы журнала «Украинская жизнь» (1912-1917 гг.)
}

\author{
Трофимов P.B. \\ Белгородский государственный национальный исследовательский университет, \\ Россия, 308015, г. Белгород, ул. Победы, 85 \\ E-mail: troro@mail.ru
}

\begin{abstract}
Аннотация. В статье рассматривается история создания и концепция московского журнала «Украинская жизнь» (1912-1917 гг.). Целями периодического издания была пропаганда идей украинского движения в российском обществе, разрушение концепции «Большой русской нации» (мало-, бело- и великороссов), создание нарратива об отдельном «украинском» этносе. Проведен контент-анализ статей журнала, выявлены основные темы «Украинской жизни»: «украинский вопрос» в России и Австро-Венгрии (на территории Галиции), русско-украинские отношения, история Украины и России, проблема признания украинской нации, дискуссии с русскими деятелями, актуальные стратегии для украинского движения. Автор пришел к выводу о сепаратистском характере журнала, который умело обходил достаточно либеральную цензуру Третьеиюньской монархии.
\end{abstract}

Ключевые слова: журнал «Украинская жизнь», «украинский вопрос» в Российской империи, малороссы, сепаратизм, С.В. Петлюра, М.Г. Грушевский.

Для цитирования: Трофимов Р.В. 2021. Создание и концептуальные основы журнала «Украинская жизнь» (1912-1913 гг.). Via in tempore. История. Политология. 48 (3): 694-705. DOI 10.52575/2687-0967-2021-48-3-694-705.

\section{Creation and conceptual foundations of the magazine «The Ukrainian life» (1912-1917)}

\author{
Roman V. Trofimov \\ Belgorod National Research University, \\ 85 Pobedy St., Belgorod, 308015, Russia \\ E-mail: troro@mail.ru
}

\begin{abstract}
The article examines the history of creation and the concept of the Moscow magazine «The Ukrainian Life» (1912-1917). The goals of the periodical were the propaganda of the ideas of the Ukrainian movement in Russian society, the destruction of the concept of the «Big Russian nation» (Little, White and Great Russians), the creation of a narrative about a separate «Ukrainian» ethnic group. A content analysis of the magazine's articles was carried out, the main topics of the «Ukrainian life» were revealed: the "Ukrainian question» in Russia and Austria-Hungary (on the territory of Galicia), Russian-Ukrainian relations, the history of Ukraine and Russia, the problem of recognizing the Ukrainian nation, discussions with Russian leaders, actual strategies for the Ukrainian movement. The author came to the conclusion about the separatist nature of the magazine, which skillfully bypassed the rather liberal censorship of the June Third Monarchy.
\end{abstract}

Keywords: magazine «Ukrainian life», «Ukrainian question» in the Russian Empire, Little Russians, separatism, S.V. Petlyura, M.G. Grushevsky. 
For citation: Trofimov R.V. 2020. Creation and conceptual foundations of the magazine «The Ukrainian life» (1912-1917). Via in tempore. History and political science. 48 (3): 694-705 (in Russian). DOI 10.52575/2687-0967-2021-48-3-694-705.

\section{Введение}

Во время существования Третьеиюньской монархии в России влияние средств массовой информации на русское общество было велико, и это понимали деятели украинского движения, которые в периодике пропагандировали свои идеи не только на малорусских землях, но и считали важным донести свою позицию на читателя всей России. Возникла идея издавать журнал в столице России - в Санкт-Петербурге, и с 1906 года начал свой выход еженедельник «Украинский вестник». Недолго просуществовавший, он в этом же году был закрыт. Спустя 6 лет с подобной тематикой в Москве стал выходить журнал «Украинская жизнь» как главный орган украинского движения в России. Предложение об издательстве украинского русскоязычного периодического органа в Москве было высказано на заседании «Украинской секции общества славянской культуры» 20 апреля 1911 года. В самой секции состояли такие деятели, как Ф. Корш, А. Крымский и Н. Янчук, поэт и геолог М. Филянский, историк искусства А. Новицкий, юристы Б. Кистяковский, И. Лебединский и С. Хвостов, журналисты С. Петлюра и А. Саликовский [Безкровний, 2019]. Именно они стали постоянными авторами статей в новом журнале. Редакторами журнала «Украинская жизнь» в разное время были Александр Фомич Саликовский (1912, 1915-1917) и Симон Васильевич Петлюра (1912-1915), редактором-издателем - Яков Андроникович Шеремецинский (1912-1917) [Кузьменко, 2020 , с. 155]. Редакция и контора «Украинской жизни» содержались на Новинском бульваре, 103, помещение 39.

Как считает современный украинский исследователь Ю. Безкровный, утверждению программы журнала в Москве «...способствовала ее нейтральность и русскоязычный статус журнала» [Безкровний, 2015, с. 87]. На самом деле нейтральность журнала была видимой, и редакторы журнала А. Саликовский и С. Петлюра, описывая журнал как, прежде всего, культурно-просветительский, скрывали его политическую направленность. Разрешение на издательство в Московском комитете по делам печати было получено.

\section{Объекты и методы исследования}

Объектами исследования являются основные идеи, концептуальные основы, деятельность журнала «Украинская жизнь» (1912-1917 гг.). Проанализирована тематика и особенности создания издания. Для комплексного освещения проблемы научной работы, которая лежит в исторической плоскости, закономерным стало решение совместить общенаучные (индукция и дедукция, анализ и синтез, абстрагирование и другие), специальные исторические (генетический, историко-сравнительный, проблемно-хронологический и т. п) и междисциплинарный (контент-анализ) методы.

В соответствии с принципами исторического и логического методов освещены организационные основы, идеологическое направление, тематика журнала «Украинская жизнь».

\section{Результаты и их обсуждение}

В Москве же украинские деятели стремились убедить русскую публику в существовании «украинцев». Современник «Украинской жизни», русский националист из ККРН С.Н. Щеголев в своем исследовании описал, что предшествовало возникновению этого журнала. Так, украинские детали «...еще в начале 1911 г. мотивировались агитацией 
газеты "Рада". Русской интеллигенции и русской прессе необходимо, по мнению “Рады", дать понять, что “хохлы” составляют особый народ, с собственной историей, культурой и языком» [Щеголев, 1912, с. 189].

В первом выпуске было опубликовано описание журнала: «Журнал выходит на русском языке в обычном формате ежемесячников книжками размером 5-6 печатных листов. Задачу “Украинской жизни" составляет служение интересам и нуждам 30-миллионного украинского народа и ознакомление общества с украинским национальным движением» [Украинская..., 1912, с. 1]. Таким образом, подчеркивался проукраинский характер журнала, утверждалось существование отдельного «украинского народа» вопреки официальной государственной политике «большой русской нации» (триединый русский народ, состоящий из велико-, мало- и белорусов).

Итак, в журнале категорически опровергались идеи, согласно которым украинцы (или малороссы) являются субэтносом русских: «”Украинская Жизнь” [...] главной своей целью ставит ознакомление русского общества и русской прессы с национальными интересами малорусского племени [...] редакция ставит своею целью разоблачение и критику тех quasi-научных теорий, которые и в России, и за рубежом под влиянием отнюдь не научных мотивов стремятся упразднить саму украинскую национальность. Не меньше внимания редакции придется уделять защите украинского национального движения о той клевете и инсинуации, которые беспрепятственно и беззастенчиво сеются представителями русского воинствующего национализма» [От редакции, 1912, с. 9]. Своего главного врага журнал видел в русском национализме, который концептуально отвергал существования отдельного украинского народа. Активные дискуссии с русскими националистами-малороссами неоднократно велись на страницах журнала.

Эта активная борьба «малороссов - русских националистов» и «малороссов - украинских националистов» стала ключевой в определении будущего Юга России. Об этой борьбе написал в своей статье А.И. Миллер: «...украинские активисты и малороссыантиукраинцы из ККРН [Киевского клуба русских националистов - Р.Т.] обращались к одному и тому же местному читателю, то есть к тому политически еще не определившемуся малороссу, хохлу, которого одни хотели сделать украинским националистом, а другие - националистом русским. Прежняя борьба за интерпретацию понятия "малоросс“ дополнилась борьбой за умы и сердца реальных людей. Следуя логике этой борьбы, оба лагеря, состоявшие из выходцев из одной среды и часто хорошо знакомых друг с другом, старались представить друг друга в самом черном цвете» [Миллер, 2018]. Таким образом, украинское движение ставило свой целью «объяснить» малороссу, что он «украинец», то есть представитель иной нации.

М.Г. Грушевский отметил, что этот журнал был «...”для наружного употребления“, для русской публики, в нем было принято писать так, как положено выступать перед чужими, не вынося внутренних дел и не очень ставя дело "во весь рост“ - даром, что русских читателей у нее [«Украинской жизни» - Р.Т.] было очень мало, читали в основном украинцы, и это не нравилось многим (и мне в том числе), что определенные категории обрусевших украинцев поддерживают сей российский журнал для обихода внутреннего, как более им близкий и милый, чем журналы украинские» [Грушевський, 1989, с. 107-108]. Грушевский с горестью отмечает, что «Украинская жизнь» осталась единственным украинским органом, которым он вынужденно пользовался.

Вернемся к характеристике журнала «Украинской жизни», которая выходила на протяжении 5 лет - с января 1912 года по июнь 1917 года. В планах было сделать журнал ежемесячным, однако многие номера по разным причинам объединяли в себе несколько месяцев. В таблице показаны все выпуски журнала. 
Все выпуски журнала «Украинская жизнь» (1912-1917 гг.) [авторская разработка] All issues of the magazine «Ukrainian Life» (1912-1917)

\begin{tabular}{|c|c|c|c|}
\hline Год выпуска & Номер выпуска & Месяц выпуска & Количество страниц \\
\hline \multirow[t]{11}{*}{1912} & № 1. & Январь & 146 \\
\hline & № 2. & Февраль & 120 \\
\hline & № 3 . & Март & 126 \\
\hline & № 4. & Апрель & 124 \\
\hline & № 5 . & Май & 128 \\
\hline & № 6. & Июнь & 128 \\
\hline & № $7-8$. & Июль-август & 154 \\
\hline & № 9 & Сентябрь & 124 \\
\hline & № 10 . & Октябрь & 128 \\
\hline & № 11 . & Ноябрь & 104 \\
\hline & № 12 . & Декабрь & 138 \\
\hline \multirow[t]{11}{*}{1913} & № 1 & Январь & 150 \\
\hline & № 2 . & Февраль & 118 \\
\hline & № 3 . & Март & 114 \\
\hline & № 4 & Апрель & 114 \\
\hline & № 5 & Май & 114 \\
\hline & № 6 & Июнь & 114 \\
\hline & № 7-8 & Июль-август & 154 \\
\hline & № 9. & Сентябрь & 122 \\
\hline & № 10 . & Октябрь & 114 \\
\hline & № 11 . & Ноябрь & 125 \\
\hline & № 12 & Декабрь & 129 \\
\hline \multirow[t]{8}{*}{1914} & № 1 & Январь & 132 \\
\hline & № 2 & Февраль & 162 \\
\hline & № 3 & Март & 137 \\
\hline & № 4 & Апрель & 117 \\
\hline & № 5-6 & Май-июнь & 126 \\
\hline & № 7. & Июль & 9 \\
\hline & № 8-10. & Август-сентябрь-октябрь & 107 \\
\hline & № $11-12$. & Ноябрь-декабрь & 124 \\
\hline \multirow[t]{8}{*}{1915} & № 1 & Январь & 103 \\
\hline & № 2 . & Февраль & 113 \\
\hline & № 3-4. & Март-апрель & 185 \\
\hline & № 5-6 & Май-июнь & 138 \\
\hline & № 7. & Июль & 165 \\
\hline & № 8-9 & Август-сентябрь & 161 \\
\hline & № 10 & Октябрь & 129 \\
\hline & № $11-12$. & Ноябрь-декабрь & 178 \\
\hline \multirow[t]{9}{*}{1916} & № 1 & Январь & 106 \\
\hline & № 2. & Февраль & 114 \\
\hline & № 3 & Март & 106 \\
\hline & № 4-5. & Апрель-май & 156 \\
\hline & № 6. & Июнь & 90 \\
\hline & № 7-8. & Июль-август & 153 \\
\hline & № 9. & Сентябрь & 94 \\
\hline & № $10-11$. & Октябрь-ноябрь & 165 \\
\hline & № 12. & Декабрь & 114 \\
\hline \multirow[t]{2}{*}{1917} & № $1-2$ & Январь-февраль & 113 \\
\hline & № 3-6 & Март-апрель-май-июнь & 200 \\
\hline
\end{tabular}


Таким образом, за более чем 5 лет существования издания всего было выпущено 49 номеров, средний объем выпуска - 128 страниц ( $\approx 7,5$ печатных листов). Журнал представлял собою сборник статей деятелей украинского движения и делился на несколько непостоянных рубрик: 1) «На текущие темы»; 2) «Обзор украинской жизни»; 3) «На Украине и вне ее»; 4) «Библиография», 5) «Объявления»; 6) «Украинская пресса», 7) «Из русской печати», 8) «Ответы читателям» и т. д.

Если подробнее рассмотреть тематику статей с 1912 по 1916 гг. выхода журнала, то сама редакция разделила на следующие рубрики [Украинская, 1917, с. 1-44]:

I. От редакции - всего 10 статей, обычно располагавшиеся в начале журнала. Здесь редакция в краткой форме описывала мнение всей редакции по актуальной теме, например, после начала Первой мировой войны журнал единодушно высказался в поддержку России и призвал украинцев сделать аналогичный выбор [Война, 1912, с. 3-7].

II. История, воспоминания, археология. Опубликовано 50 статей. В центре внимания была проблема истории Украины: концептуальные основы изложены, например, в статье М.С. Грушевского «Украина и украинство». Автор находит украинцев в догосударственный период Древней Руси, особо акцентирует внимание на «украинском» характере Киевской и Галицко-Волынской Руси. После украинцы были разделены между Литвой (потом - Польшей) и Московским княжеством (потом - Русским царством и Российской империей) [Грушевский, 1912, с. 11]. Авторы журнала рассматривали «Украинский вопрос» в различные исторические эпохи: времен Алексея Михайловича Романова [Сиромаха, 1912], Петра I [Пичета, 1915], Дворцовых переворотов [Пичета, 1916], Декабристского восстания [Василенко, 1912]. В этом же разделе представлены мемуары о деятельности и взглядах украинских деятелей: Т.Г. Шевченко, М.С. Грушевского, П.П. Чубинского, Б.Д. Гринченко, М.П. Драгоманова, М.М. Коцюбинского и других.

III. История литературы и литературная критика представлена 28 статьями. В этом блоке журнала представлены рецензии, впечатления авторов журнала об украинской литературе. Особое внимание уделялось таким писателям, как Т. Шевченко, И. Франко, Л. Украинка, В. Винниченко, М. Коцюбинский.

IV. Юбилейные статьи, заметки, биографии и некрологи. Этот раздел представлен 47 статьями, в которых описывались биографии, отдавалась дань известным украинофильским деятелям - писателям, культурным деятелям, ученым, активистам: М.П. Драгоманов, И.Я. Франко, Ф.Е. Корш, Т.Г. Шевченко, М.С. Грушевский, К.П. Михальчук, А. Шептицкий, А.А. Русов, И.И. Костомаров, А.Ф. Кистяковский, Н.В. Лисенко, Ю.Ю. Цветковский и т. д.

V. Этнография и филология. Всего 7 статей, касающиеся языкового вопроса и этнографии. Усилия авторов были направлены, прежде всего, на утверждение отдельности «украинского языка», противодействие наименованию «малорусское наречие», активной критике сторонников общерусского языка. Для наглядности взглядов авторов журнала приведем цитату из статьи «На страже научной правды и объективности», где автор клеймит русских филологов из-за их нежелания признавать малорусское наречие украинским языком: «Конечно, для современного украинства эти языковые дебаты являются до известной степени пройденным этапом, теперь они потеряли уже значительную долю своей остроты и актуальности, - украинский язык via facti, не дождавшись благословения наших ученых и вопреки им, уже вышел на широкую общественную и культурную арену, порвав навсегда с позорным для него положением “для домашнего обихода”» [Вол, 1914].

Из этого следует, что, во-первых, в российской науке к началу XX века не определились со статусом украинского языка, склоняясь классифицировать его как наречие русского языка, а во-вторых, подобная трактовка проблемы вызывала ожесточение среди украинских деятелей, не терпящих никаких возражений “via facti”.

VI. Искусство. 21 статья, которая посвящена украинскому театру, архитектуре, церковному зодчеству, музыке, орнаменту, народным песням, изобразительному искусству. 
VII. Право и экономика. 26 статей, касающихся проблем сельского хозяйства, капитализма и законодательства на Украине: землевладение, развитие капитализма, статистические и демографические справки, развитие кооперативного движения, экономические взаимоотношения Украины с «Великороссией» и Польшей, реформирование суда, кодификация права. Обращают внимание характерные формулировки о значении Украины для экономики России, где автор К. Оберучев приводит цитату другого публициста М. Гехтера: «Украина для России не только "житница“, как пишется во всех хрестоматиях, а и склад мяса, ртути, глины, железной руды, чугуна, стали, каменного угля, свеклы, сахара и пр. [...] Невольно возникает вопрос: что делала бы Россия, если бы каким-нибудь образом она оказалась не над Украиной, а рядом с нею. Такое положение даже представить трудно, а сравнить его можно разве только с положением города, в котором вдруг забастовало бы большинство пекарей, резников, угольщиков, продавцов сахара, вообще всех предметов первой необходимости» [Оберучев, 1912, с. 37].

Таким образом, что касается экономического взаимодействия внутри огромной Российской империи, главный тезис сторонников украинской идеи заключался в том, что «Украина кормит остальную Россию». Это попытка выставить малорусские земли в качестве «сырьевого придатка» и колонии России. Это утверждение повторялось и в будущем, на протяжении XX и XXI века многими украинскими публицистами и политиками: «Украина - бывшая самая большая и самая важная колония московской империи» [Парахонський , 2019. с. 304], - один из ключевых нарративов украинской идеи.

VIII. Публицистика (207 статей), которая делится на следующие рубрики:

1. «Общие вопросы» - текущие проблемы политической жизни, ответы оппонентам по различным вопросам, дальнейшие задачи украинского движения.

2. «Галичина, Буковина и Угорская Русь». Особенно активно публикации по данной тематике начались с началом Первом мировой войны и занятием русскими войсками территории Восточной Галиции. Здесь украинофилы особое внимание уделяли «москвофильству» (т. е. русофильству) русинских деятелей. В журнале «Украинская жизнь» галицкие русские произведения и взгляды называли никак иначе как «...беззастенчивая мистификация, беспочвенная утопия, выдаваемая за подлинную действительность, цепь извращений, умолчаний, ложных ссылок, словом, целая система ухищрений, направленная на „обработку” русского общественного мнения» [Ядий, 1916, с. 78]. Подобные резкие высказывания могли позволить себе деятели украинского движения против других малороссов из Киевского клуба русских националистов (ККРН).

3. «Русско-украинские отношения». Статьи этого «подраздела» привлекают особенное внимание, ведь в них изложены основные дискуссионные проблемы между русскими деталями: русофилами (выступающими против украинства) и украинофилами. Первый лагерь представлен как малороссами (С. Щеголев, В. Шульгин, А. Савенко, Д. Пихно и др.), так и великороссами (П. Струве, В. Розанов, кн. Е. Трубецкой и др.). Важно также отметить, что и «лагерь» украинофилов состоял как из малороссов (представленные редакцией и основными авторами журнала), так и великороссов по культуре, которые либо полностью поддерживали украинство, либо относились к нему с симпатией (Ф. Корш, М. Горький, А. Луначарский и др.). По нашему мнению, было бы ошибкой считать, что борьба вокруг украинства велась сугубо между мало- и великороссами (украинцами и русскими, говоря современным языком). В обоих лагерях был смешанный, русскоукраинский состав, и отношение к украинскому вопросу в больше степени определялось не этнической, а политической принадлежностью: деятели право-монархического толка относились к украинству крайне негативно, в то время как либеральные и левые политики и публицисты в целом одобряли украинские идеи. Этот подраздел представлен 46 статьями и является одной из центральных в «Украинской жизни».

4. «Польско-украинские отношения». В журнале было опубликовано 10 статей на польскую тематику. Интересно, что украинские публицисты, признавая сложные истори- 
ческие взаимоотношения между малороссами и поляками, явно солидаризируются: «В силу совершенно понятных причин польское общество относится к украинскому движению в России с симпатией [...] Весьма возможно, что в более или менее отдаленном будущем явится даже настоятельная потребность создать известное соглашение чисто практического характера родственных по духу и идейным стремлениям польских и украинских элементов» [Василевский, 1912, с. 41]. Вполне закономерно, что украинцы в своем стремлении к «федерализации» России искали союзников, в том числе и среди поляков, многие из которых стремились к возрождению независимой Польши.

5. «Холмский вопрос». Этой теме посвящено в журнале 4 статьи, оценивающие политику Российской империи в связи с изъятием из управления Варшавского генералгубернаторства Холмской губернии, которая была населена преимущественно малороссами.

6. «Белорусский вопрос». В журнале опубликовано 3 статьи белорусского публициста М.А. Богдановича, который писал о «белорусском возрождении»: «белорусский народ не tabula rasa, а самостоятельная национальная величина, белорусское же движение - живая культурно-общественная сила» [Богданович, 1915, с. 62]. Закономерно, что украинское движение находило союзников среди сторонников «белорусской идеи» и всячески поддерживало стремление белорусского народа к суверенитету.

Помимо указанных тем в публицистике появлялись статье на темы: «Украинский вопрос» и Государственная Дума; национальная школа; положение украинской печати; украинские культурно-просветительские, научные и общественные организации; украинцы вне Украины; земство на Украине и т. д.

Используя междисциплинарный подход, можно применить метод контент-анализа. Контент-анализ - это своеобразный метод сбора количественных данных о явлении, которое исследуется, или процессе, который содержится в документах.

Чаще всего различия в определении контент-анализа обусловлены тем, какой тип контент-анализа исследователи предпочитают - количественный или качественный [Пашинян, 201, с. 14].

Количественный контент-анализ основывается на анализе частоты упоминаний, выбранных исследователем содержательных единиц, соотношение частоты их появления в видео/тексте/фото, оценок, с которыми они упоминаются. Количественный контент-анализ применяется при анализе больших массивов информации. При качественном контентанализе исследователь сосредоточивается не на количестве появления определенных смысловых единиц в тексте, а на факте их присутствия или отсутствия, на анализе их сущности, форме подачи. Как правило, качественный контент-анализ применяется в отношении небольших по объему текстов или отдельных смысловых единиц. В сложных комплексных исследованиях количественный и качественный контент-анализы объединяют, что дает возможность использовать преимущества обоих методов [Дмитриева, 2009, с. 137].

Задачами исследования будет определение наиболее частых тем, затрагиваемых в «Украинской жизни». Проведя количественный контент-анализ заголовков статей, мы выяснили, что семантическое ядро составляют слова «украинский» (количество упоминаний - 319) «Украина» (97 упоминаний), «вопрос» (60 упоминаний), «Галиция» и «Галичина» (53 и 36 упоминаний соответственно), «национальный» (33 упоминания) «русский» и «русская» (32 и 30 упоминаний), общество (25 упоминаний), «украинец» (25 упоминаний), «история» (24 упоминания). Среди наиболее частых авторов журнала - С.А. Ефремов (48 публикаций), С.В. Петлюра, Д.И. Донцов и В.В. Садовский (по 29 публикаций), Л.И. Бурчак (21 публикация), М.С. Грушевский (17 публикаций), С.Ф. Русова (14 публикаций), М.М. Могилянский (13 публикаций), А.Ф. Саликовский (12 публикаций).

Таким образом, контент-анализ позволил нам определить основные наиболее волновавшие темы авторов журнала: украинство, Галиция, русско-украинские отношения, проблемы национального строительства, истории и общества. 
Дела у «Украинской жизни» в первый год шли не очень хорошо. Так, в «Дневнике» Е. Чикаленко пишет: «Издатели [«Укр. Жизни» - Р.Т.] пишут, что, несмотря на то, что у них 800 подписчиков, уже не на что издавать журнал, потому что все деньги потрачены на гонорары, на печать, бумагу и т. п. И просят раздобыть денег, чтобы хоть закончить год. Вот горе! Пресса наша на украинском языке прозябает, то из-за притеснений, то через непонятность языка для широкой людности, ну а чего уже должна погибать "Украинская Жизнь“, которая выдается понятным языком и не преследуется администрацией, как пресса на украинском языке?» [Чикаленко, 2011, с. 243]. Уже через год Чикаленко в мемуарах вновь волнуется, что «Украинскую жизнь» закроется из-за дальнейшего падения интереса и падения количества подписчиков [Там же, с. 280]. Основывая журнал, редакция «...рассчитывала на российского читателя, а оказалось, что выписывают ее почти исключительно украинцы» [Там же, с. 308].

Современный украинский исследователь И.Б. Гирич, отмечая важность «Украинской жизни», признает, что все годы своего существования журнал «балансировал на грани банкротства» [Гирич, 2014, с. 13]. Это же отмечает О.О. Полумысная: «Над изданием «Украинской жизни» постоянно висело бремя нехватки средств. Длительное время редакция журнала располагалась в квартире С. Петлюры на улице Большая Дмитровка, 14. И только благодаря поклонникам журнала, их материальной поддержке журнал имел возможность существовать» [Полумисна, 2009, с. 193].

М.Э. Клопова, проведя анализ работы «Украинской жизни», пришла к выводу, что «“Украинской жизни” не удалось занять того места, на которое рассчитывали его создатели: места рупора украинского движения, его представителя в среде прогрессивной общественности» [Клопова, 2015, с. 135]. Главной ошибкой украинских деятелей, по мнению исследовательницы, было то, что они не понимали причин «равнодушия» российской интеллигенции к украинскому вопросу, хотя на самом деле русские деятели охотно интересовались украинством, но их реакция и ответы не устраивали редакцию, как результат возникали противоречия между общероссийскими и украинскими интересами. Согласимся с М.Э. Клоповой, но с оговоркой, что противоречия были, по нашему мнению, из-за того, что главной целью украинских деятелей был сепаратизм, отделение Малороссии от остальной России, в то время как русских прогрессивных деятелей интересовала судьба единой демократической России.

По мнению современного исследователя В.Э. Савчинского, издания вроде «Украинской жизни» умело обходили цензурные и общественные запреты: «...представители умеренного крыла украинофильского движения в период войны не выносила в практическую плоскость вопросы национально-государственного устройства. Тем более что в период войны постановка данного вопроса даже в дискуссионном формате могла привести к радикальным мерам со стороны силовых структур Российской Империи» [Савчинский, 2020, с. 61]. Согласимся с исследователем, что планам украинофилов суждено уже сбыться после февраля 1917 года.

Согласимся с мнением А.В. Прохоренко, который отметил, что «Адепты украинской самобытности были поставлены в тяжелейшие условия, когда против них работала и историческая наука, и религия, и традиции, а главное - предрассудки самого же украинского народа, враждебно относившегося к идее своей самобытности. Но тем не менее им удалось справиться со своей задачей - создать идеологию украинского национализма, хотя для этого пришлось переписать историю, создать литературу и язык, придумать даже название для своей национальности и заставить народ принять его, что свидетельствует о высоких интеллектуальных способностях теоретиков украинства» [Прохоренко, 2006, с. 115]. Добавим к этому, что становлению украинства во многом помогли сами российские деятели - сначала после Февральской революции либеральные и левые (социалдемократы, эсеры) политики, а вскоре - большевики, которые перекроили границы исторической России, присоединив к новосозданному украинскому государству территории 
Северного Причерноморья, Донбасса (в городах которых преобладала великорусская народность и культура), наконец, провели ликвидацию безграмотности на украинском языке, украинизацию, уничтожив легитимность понятия о Малороссии и малороссах, назвав их «шовинистическими» и «великодержавными».

Не зря многие украинские деятели во главе с М.С. Грушевским вернулись в УССР, активно поддерживая политику большевиков касательно украинского вопроса. По нашему мнению, конечно, украинские деятели самоотверженно боролись за свою идею, однако, найдя такого мощного союзника в лице русского либерализма, а потом в лице левых радикалов (большевиков), ненавидевших «великодержавные» идеи, украинство получила полную свободу для деятельности и «дерусификации» малороссов. После нескольких десятилетий советской власти понятие «украинец» стало полноценным этнонимом, обозначением полноценной национальности. Все русские патриоты-малороссы были названы «шовинистами» и врагами советской власти, многие были репрессированы, а уцелевших эмигрантов не публиковали в СССР. Только сейчас, осознавая масштабы террора против малорусского движения, отечественная наука пересматривает свои взгляды на украинское движение как на главного выразителя надежд и желаний малорусского (украинского) народа.

\section{Заключение}

Таким образом, «Украинская жизнь» выходила для того, чтобы донести свою позицию по «Украинскому вопросу» русской интеллигенции, активно противостоять своему главному врагу - русским националистам в Малороссии. В свою очередь, вызывает вопросы чрезмерная либеральная, по нашему мнению, национальная политика властей Российской империи, власти которой прекратили всякую борьбу с украинским движением, не видели в ней достаточно серьезной опасности. Более того, Николем II в 1905 году был фактически отменен Эмский указ 1876 года, ограничивавший использование малорусского наречия (в современном понимании - украинского языка). Это усилило позиции украинофилов, ведь признание отдельного языка могло трактоваться как признание со стороны империи отдельной нации [Вульпиус, 2005, с. 191]. За открытую поддержку украинского движения не то что никто не преследовал, проукраинские статьи проходили цензуру и печатались на всю страну. Современный украинский исследователь Д.И. Миронюк, не скрывая своего восторга, пишет, что именно благодаря «Украинской жизни» русские и украинцы смоги убедиться в том, что «...У Ураина опиралась на достаточно прочные экономические основы, которые давали ей право на самоопределение и строительство суверенного независимого государства» [Миронюк, 2011, с. 14]. Подобная характеристика деятельности издания в который раз убеждает в слабости цензурных ограничений в России, если на территории страны выходит журнал, который поддерживает сепаратистский проект. Не согласимся с современными украинскими исследователями, которые часто пишут об «ужасных преследованиях». Так, Н.С. Тимошик пишет: «...в условиях ужасной реакции, последовательного неприятия официальными властями всего, что связано с идеей украинства, систематический ежемесячный приход журнала в течение ряда лет к все возрастающему числу читателей сегодня воспринимается настоящим подвигом» [Українське..., 1997, с. 15-16].

Скорее, как показывает анализ журнала, отметим, что власть России, несмотря на многочисленные предупреждения русских государственников об угрозе украинского сепаратизма, не только разрешала печататься на украинскую тему украинофилам на русском языке (журнал «Украинская жизнь»), но и на украинском. Например, в разгар войны, в 1916 году на малорусском наречии выходил журнал «Промінь» под руководством М.С. Грушевского [Промінь, 1916-1917]. По нашему мнению, современная украинская историография чрезмерно преувеличивает «ужасность» борьбы с украинским движением, особенно странно это выглядит, когда об этом пишут исследователи украинских периодических изданий, издававшихся в Российской империи. 


\section{Список источников}

1. «Украинская жизнь», журнал (Москва). 1917. Указатель статей и заметок, напечатанных к «Украинской жизни» в 1912-1916 г. Москва: 44.

2. Богданович М. 1915. Белорусское возрождение. (Окончание). Украинская жизнь. 2: $53-62$.

3. Василевский (Плохоцкий) Л. 1912. Спорные вопросы в области польско-украинских отношений. Украинская жизнь. 10: 39-51.

4. Василенко Н. 1912. Декабрист об Украине (В.И. Маслов. Литературная деятельность К.Ф. Рылеева. Киев. 1912). Украинская жизнь, 3: 84-91.

5. Война и украинцы. 1912. Украинская жизнь, 2: 3-7.

6. Вол. Я. 1914. На страже научной правды и объективности. Украинская жизнь. 4: 13-19.

7. Грушевский М.С. 1912. Украина и украинство. Украинская жизнь, 1: 11-28.

8. Грушевський М. 1989. Спомини. Київ: Щомісячний літературно-художній та громадсько-політичний журнал Спілки письменників України та Київської письменницької організації., Київ, 8: 102-154.

9. Оберучев К. К 1912. вопросу об экономических отношениях Украины к Великороссии и Польше. Украинская жизнь. 3: 37-45.

10. От редакции. Наши задачи. 1912. Украинская жизнь, 1: 5-10.

11. Пичета В.И. 1916. Верховный Тайный Совет и малороссийские дела. Украинская жизнь, 6: 32-53.

12. Пичета В.И. 1915. Федор Салтыков, современник Петра I, о политике России по отношению к Малороссии. Украинская жизнь, 8-9: 101-104.

13. Промінь: Тижневик літератури, науки, мистецтва и громадського життя. М., Л. Сологуб, 1916-1917.

14. Сиромаха Д. 1912. Соединение Украины с Москвою. Украинская жизнь, 2: 55-68.

15. Украинская жизнь, 1912. 1: 1.

16. Чикаленко С. Щоденник (1907-1917). / С. Чикаленко, Київ: Темпора, 2011, 480.

17. Щеголев С.Н. 1912. Украинское движение как современный этап южно-русского сепаратизма, Киев, 588.

18. Ядий Н. 1916. Москвофильская утопия и объективная действительность. Украинская жизнь, 2.: 50-79.

\section{Список литературы}

1. Безкровний Ю.О. 2015. Журнал «Украинская жизнь» і цензура (1912-1917). Етнічна історія народів Свропи., Вип. 46.: 86-92.

2. Безкровний Ю.О. Українська секція товариства слов'янської культури. Енциклопедія iсторії України: Україна - Українці. Кн. 2. Сайт Института истории Украины HAH Украины, URL: http://www.history.org.ua/?termin=ukrajinska_sektsija_tovarystva_slov'janskoji_kultury (дата обращения: 01.09.2021).

3. Вульпиус Р. 2005. Языковая политика в Российской Империи и украинский перевод Библии (1860-1906). Ab imperio, 2/2005., Казань; Нью-Йорк: 191-224.

4. Гирич І.Б. Українська преса початку XX століття: нівеляційний російський тиск $\mathrm{i}$ здатність до національної опірності. Українофобія як явище та політтехнологія: Збірник статей, Львів, 2014., Вип. 1.: 11-21.

5. Дмитриева Л.М. 2009. Социальная реклама. М., ЮНИТИ-ДАНА, 272.

6. Клопова М.Э. 2015. «Больной вопрос». Анкета журнала «Украинская жизнь» 1912-1917 гг. Славянский альманах. 3-4: 122-137.

7. Кузьменко Т.А. 2020. Из эпистолярного наследия редакторов журнала «Украинская жизнь». Славянский альманах. 1-2: 154-164.

8. Миллер А.И. Неуловимый малоросс: историческая справка. Россия в глобальной политике, 2.2018 [Электронный ресурс]. Сайт журнала Россия в глобальной политике. URL: https://globalaffairs.ru/articles/neulovimyj-maloross-istoricheskaya-spravka/ (дата обращения: 01.09.2021). 
9. Миронюк Д.І. 2011. Симон Петлюра як редактор журналу «Украинская жизнь» (1912.1917 рр.): автореф. дис. канд. наук із соц. комунікацій: 27.00.04. Д. І. Миронюк; Київ. нац. ун-т ім. Т. Шевченка. Київ, 20.

10. Пашинян И.А. 2012. Контент-анализ как метод исследования: достоинства и ограничения. Научная периодика: проблемы и решения, 3: 13-18.

11. Полумисна О.О. 2009. Організаційна діяльність редакторського складу журналу «Украинская жизнь» (1912-1917 рр.). Вісник Харківського національного університету ім. В.Н. Каразіна., 846. Сер.: Філологія, Вип. 56.: 191-196.

12. Прохоренко А.В. 2006. Украинский вопрос в идейной полемике российской пореволюционной эмиграции. Вече. СПб., Вып. 16: 115-176.

13. Савчинский В.Э. 2020. «Украинский вопрос» в 1917 г.: поиск компромиссов или отсутствие альтернатив. Парадигмы истории и общественного развития, 17-18: 61-69.

14. Парахонський Б.О., Яворська Г.М. 2019. Онтологія війни і миру: безпека, стратегія, смисл: монографія. Київ, НІСД, 560.

15. Українське питання. Укр. пер., упоряд., передм. та прим. 1997. М. Тимошик. Київ, Вид-во ім. Олени Теліги, 218.

\section{References}

1. Bezkrovnij Y. 2015. Zhurnal «Ukrainskaya zhizn'» i cenzura (1912-1917) [The magazine «Ukrainian life» i censorship (1912-1917)]. Etnichna istoriya narodiv Evropi. Vip. 46: 86-92 (in Ukrainian).

2. Bezkrovnij Y.O. 2019. Ukraïns'ka sekciya tovaristva slov'yans'koï kul'turi [Ukrainian section of the fellowship of words' culture]. Enciklopediya istoriï Ukraïni: Ukraïna - Ukraïnci. Kn. 2. sajt Instituta istorii Ukrainy NAN Ukrainy, URL: http://www.history.org.ua/?termin=ukrajinska_sektsija_tovarystva_slov'janskoji_kultury (Data obrashcheniya: 01.09.2021) (in Ukrainian).

3. Vul'pius R. 2005. Yazykovaya politika v Rossijskoj Imperii i ukrainskij perevod Biblii (1860-1906) [Language policy in the Russian Empire and the Ukrainian translation of the Bible (1860-1906)]. Ab imperio, 2.2005. Kazan'; N'yu-Jork: 191-224 (in Russian).

4. Girich I.B. 2014. Ukraïns'ka presa pochatku HKH stolittya: nivelyacijnij rosijs'kij tisk i zdatnist' do nacional'noï opirnosti [Ukrainian press of the early twentieth century: leveling Russian pressure and the ability to national resistance]. Ukraïnofobiya yak yavishche ta polittekhnologiya: Zbirnik statej, L'viv, Vip. 1: 11-21 (in Ukrainian).

5. Dmitrieva L.M. 2009. Social'naya reklama [Social Advertising]. M, YUNITI-DANA, 272.

6. Klopova M.E. 2015. «Bol'noj vopros». Anketa zhurnala «Ukrainskaya zhizn'» 1912-1917 gg. [«Sick question». Questionnaire of the magazine «Ukrainian life» 1912-1917]. Slavyanskij al'manah. 3-4: 122-137 (in Russian).

7. Kuz'menko T.A. 2020. Iz epistolyarnogo naslediya redaktorov zhurnala «Ukrainskaya zhizn'»[From the epistolary heritage of the editors of the journal «Ukrainian Life»]. Slavyanskij al'manah. 1-2: 154-164 (in Russian).

8. Miller A.I. 2018. Neulovimyj maloross: istoricheskaya spravka [The elusive Little Russian: historical background]. Rossiya v global'noj politike. 2. [Elektronnyj resurs]. sajt zhurnala Rossiya v global'noj politike, URL: https://globalaffairs.ru/articles/neulovimyj-maloross-istoricheskaya-spravka/ (Data obrashcheniya: 01.09.2021) (in Russian).

9. Mironyuk D.I. 2011. Simon Petlyura yak redaktor zhurnalu «Ukrainskaya zhizn'» (1912-1917 rr.) [Simon Petliura as the editor of the magazine «Ukrainian life» (1912-1917)]: avtoref. di. kand. nauk iz soc. komunikacij: 27.00.04. D.I. Mironyuk; Kiïv. nac. un-t im. T. Shevchenka. K.: 20 (in Ukrainian).

10. Pashinyan I.A. 2012. Kontent-analiz kak metod issledovaniya: dostoinstva i ogranicheniya [Content analysis as a research method: advantages and limitations]. Nauchnaya periodika: problemy i resheniya. 3: 13-18 (in Russian).

11. Polumisna O.O. 2009. Organizacijna diyal'nist' redaktors'kogo skladu zhurnalu «Ukrainskaya zhizn'» (1912-1917 pp.) [Organizational activity of the editorial staff of the magazine «Ukrainian Life» (1912-1917 pp.)]. Visnik Harkivs'kogo nacional'nogo universitetu im. V.N. Karazina. 846. Ser: Filologiya. Vip. 56: 191-196 (in Ukrainian). 
12. Prohorenko A.V. 2006. Ukrainskij vopros v idejnoj polemike rossijskoj porevolyucionnoj emigracii [The Ukrainian question in the ideological polemics of the Russian post-revolutionary emigration]. Veche. SPb, Vyp. 16: 115-176 (in Russian).

13. Savchinskij V.E. 2020. «Ukrainskij vopros» v 1917 g: poisk kompromissov ili otsutstvie al'ternativ [«Ukrainian question» in 1917: search for compromises or lack of alternatives]. Paradigmy istorii i obshchestvennogo razvitiya. 17-18: 61-69 (in Russian).

14. Parahons'kij B.O. 2019. Ontologiya vijni i miru: bezpeka, strategiya, smisl [Ontology of war and peace: security, strategy, meaning]. Kiïv, NISD: 560 (in Ukrainian).

15. Ukraïns'ke pitannya [The Ukrainian question]. 1997. ukr. per. uporyad. peredm. ta prim. M. Timoshik. Kiïv, Vid-vo im. Oleni Teligi: 218 (in Ukrainian).

Конфликт интересов: о потенциальном конфликте интересов не сообщалось.

Conflict of interest: no potential conflict of interest related to this article was reported.

\section{ИНФОРМАЦИЯ ОБ АВТОРЕ}

Трофимов Роман Викторович, аспирант кафедры российской истории и документоведения Белгородского государственного национального исследовательского университета, г. Белгород, Россия

\section{INFORMATION ABOUT THE AUTHOR}

Roman V. Trofimov, post-graduate student of the Department of Russian History and Documentation of the Belgorod state national research University, Belgorod, Russia 